\title{
IAMJ
}

INTERNATIONAL

AYURVEDIC

MEDICAL JOURNAL

Research Article

ISSN: 2320-5091

Impact Factor: 6.719

\section{A COMPARATIVE CLINICAL STUDY TO EVALUATE THE EFFECTIVENESS OF TRYUSHSANADHI GUGGULU AND NAVAKA GUGGULU IN DYSLIPIDEMIA}

\section{Merin Jose ${ }^{1}$, Ravindra Bhat $\mathrm{K}^{2}$, Waheeda Banu ${ }^{3}$}

${ }^{1}$ PG Scholar, Department of P.G Studies in Kayachikitsa, Karnataka Ayurveda Medical College and Hospital, Mangalore, D.K District, Karnataka, India

${ }^{2}$ Professor, Department of P.G Studies in Kayachikitsa, Karnataka Ayurveda Medical College and Hospital, Mangalore, D.K District, Karnataka, India

${ }^{3}$ Professor and Head of the Department, Department of P.G Studies in Kayachikitsa, Karnataka Ayurveda Medical College and Hospital, Mangalore, D.K. District, Karnataka, India

Corresponding Author: merinjoze@gmail.com

https://doi.org/10.46607/iamj1509102021

(Published Online: October 2021)

Open Access

(C) International Ayurvedic Medical Journal, India 26021

Article Received: 20/09//2021 - Peer Reviewed: 05/10/2021 - Accepted for Publication: 07/10/2021

Check for updates

\begin{abstract}
Dyslipidemia occurs when there is an elevation in the levels of plasma cholesterol, triglycerides, or a decreased level of HDL levels. It is one of the main causes that contribute to the event of atherosclerosis and a major cause of various lifestyle disorders. Dyslipidemia being the common issue faced by mankind, there is a necessity to combat it with the drugs mentioned in the classics. In this regard, an attempt has been made to critically review the action of two important drugs mentioned in the classical texts which help in managing Dyslipidemia. The present study was aimed to assess the clinical effectiveness of Tryushanadhi guggulu and Navaka guggulu in Dyslipidemia and to compare the effectiveness of both after therapy. This comparative clinical study was conducted with pre and post designs in 40 patients diagnosed with Dyslipidemia with 20 patients in each in two groups viz Group A and Group B treated with Tryushanadhi guggulu and Navaka guggulu respectively. The assessment was done before and after the treatment with Objective criteria. After a thorough assessment, it was found out that Group A (Tryushanadhi guggulu:20.87\%) had better results compared to Group B (Navaka guggulu: $10.37 \%)$.
\end{abstract}


Keywords: Dyslipidemia, Tryushanadhi guggulu, Navaka guggulu, Medoroga

\section{INTRODUCTION}

Modernization made society follow a fast and stressful life. A sedentary lifestyle becomes the reason for the formation of many diseases. One among them is Dyslipidemia. Lipids ${ }^{1}$ can be correlated to Medas (fat/Adipose tissue) and so Medohara (Anti-Obesity) treatment can be adopted in its treatment. The term Dyslipidemia is used to describe disordered lipid metabolism in the body. Life style ${ }^{2}$ management including dietary modification, active exercise \& quitting smoking is a good measure to lower the risk associated with Dyslipidemia ${ }^{3}$. Effective weight loss lowers the raised serum cholesterol level ${ }^{4}$. Abaddha or Baddha meda dushti (disorders of fat metabolism) cited in Prameha (Urinary diseases including Diabetes) \& Sthoulya (Obesity) in Ayurveda can be deliberated as Dyslipidemia. So, Medoroga can be treated as per the lines of management of Prameha and Sthoulya. Medodushti is the abnormal accumulation of Meda dhatu in the body. Medodushti includes numerous amounts of other Medovikara, which are mutually known as Medoroga. Acharya Charaka ${ }^{5}$ has given more importance to the exogenous type of causes in Medoroga i.e., Meda potentiating regime whereas Acharya Sushruta ${ }^{6} \&$ Acharya Vagbhatta ${ }^{7}$ stressed mainly on endogenous causes including unstable functions of Dosha, Dhatu (tissues), Mala (metabolic wastes), Strotas (channels) etc. Acharya Vagbhatta especially stated that Amadosha is the cause behind Medoroga.

Acharya Charaka has acknowledged "Ahara" (Food) as the supreme common pathogenic reason for Medovriddhi / Medodushti in Medoroga whereas Acharya Sushruta has accepted Amadosha. Overeating of Sleshma-Bhuyishtha Ahara (Kapha increasing food), sedentary lifestyle, daytime sleeping, lack of exercise etc. are various etiological factors for Medoroga. Overindulgence with such types of factors leads to an increase in guru, Snigdha (oily), Manda (slow) \& Sthira Guna (static) in the body, which all are like Guna (quality) of Kapha thereby causing
Kapha Bhuyishtha Dosha Vriddhi in the body. As an individual taking a high-calorie diet but proportionately low energy expenditure due to lack of physical activity i.e., positive energy imbalance leading to accumulation of extra energy in the form of fats (lipids)i.e., excessive accumulation of Medo Dhatu.

Again, on the other hand, in modern science, psychological disorders are also associated with overeating habits, in such patients leading to excessive calorie intake \& thereby Dyslipidemia (Medoroga). Hence, Kapha and Meda dhatu two are the main doshadushya ghataka (components of Dosha Dushya) in pathogenesis. Accumulation of Kapha \& Meda leads to Srotovarodha (obstruction of channels) causing trapping of samana vayu in koshtha (anatomical body cavities) leading to Avarana (enveloping) to Samana vayu. It leads to Jatharagni Sandhukshana. Increased Jatharagni (digestive fire) leads to rapid digestion of ingested food $\&$ leaves the person craving for food. This vicious cycle continues resulting in Meda Atiupachaya. According to modern science, the digestion of fat starts in duodenum \& pancreatic lipase is the main enzyme involved thereafter resulting in the formation of free fatty acids \& monoglycerides. So, the pathology of Dyslipidemia can be well correlated with Ati Snehayukta Anna Rasa as told by Acharya Sushruta. Tryushanahi guggulu ${ }^{8}$ and Navaka guggu$l u^{9}$ mentioned in the Sthoulyadhikara. Navaka Guggulu is a well-known drug that is used widely. Hence it is taken as a trial drug to compare with Tryushanadhi guggulu which is having almost similar drugs in its combination.

\section{Aim \& Objectives}

1. To study the etiopathogenesis of Dyslipidemia.

2. To evaluate the effectiveness of Tryushanadhi guggulu and Navaka guggulu in Dyslipidemia.

3. To compare the clinical effectiveness of Tryushanadhi guggulu and Navaka guggulu in Dyslipidemia 


\section{METHODOLOGY}

\section{Sources of data}

\section{Method of collection of data}

A minimum of 40 patients fulfilling the diagnostic and inclusion criteria of either gender were selected for the clinical study. They were randomly assigned into two groups, Group A and Group B with 20 patients each.

- Group A: 20 patients were administered Tryushanadhi guggulu

- Group B: 20 patients were administered Navaka guggulu.

\section{Diagnostic Criteria}

Patients with elevated lipid profiles with or without symptoms of Sthoulya will be selected.

\section{Inclusion Criteria}

- Diagnosed \& confirmed cases of Dyslipidemia based on investigation All or any.

- Patients between the age group of 20-60 years of either sex who fulfil the criteria of Objective parameters

- Cases of NIDDM with optimal control Diabetes is also considered under study.

\section{Exclusion Criteria}

- Patients with ages below 20 years \& above 60 years

- Patients suffering from type 1 Diabetes mellitus and uncontrolled Diabetes mellitus or uncontrolled Hypertension.

- Drug-induced or uncontrolled Dyslipidemia.

- Patients have systemic illnesses like Tuberculosis, Carcinoma and Endocrine disorders or major illness like Renal or Liver disorders.
- The patient has a history of Myocardial infarction \& Unstable Angina.

\section{Investigations}

For the diagnosis and exclusion criteria's:

- Serum lipid profile

- Fasting Blood sugar if required

PROCEDURE AND DESIGN OF THE STUDY GROUP-A

\section{Plan Of Treatment}

Included patients were treated as follows:

Oral administration of two Tryushanadhi guggulu twice a day after food for 30 days with lukewarm water.

\section{Study Duration}

Treatment duration:30 days

Observation period: Before treatment $\left(0^{\text {th }}\right.$ day $)$ and after treatment ( $31^{\text {st }}$ day)

Total study duration-31 days

\section{Group B}

\section{Plan Of Treatment}

Included patients were treated as follows:

Oral administration of two Navaka guggulu twice a day after food for 30 days with lukewarm water.

\section{Study Duration}

Treatment duration:30 days

Observation period: Before treatment $\left(0^{\text {th }}\right.$ day) and after treatment ( $31^{\text {st }}$ day)

Total study duration-31 days

\section{ASSESSMENT CRITERIA}

\section{Objective Parameters}

- Complete Lipid profile including serum cholesterol, serum triglycerides, serum HDL, serum LDL, serum VLDL

As the parameters are in the measurements no scoring pattern was adopted.

\section{RESULTS}

Table 1: Statistical analysis of parameters

\begin{tabular}{|l|l|l|l|l|l|l|}
\hline Parameters & Group A (Mean Score) & Group B (Mean Score) & S.D $( \pm)$ & S.E $( \pm)$ & T Value & P-Value \\
\hline Weight & 64.73 & 63.80 & 15.082 & 3.460 & 0.28 & $>0.05$ \\
\hline TC & 210.31 & 218.01 & 34.082 & 7.819 & 0.85 & $>0.05$ \\
\hline TG & 171.28 & 186.36 & 84.750 & 19.443 & 0.80 & $>0.05$ \\
\hline HDL & 43.48 & 43.24 & 10.222 & 2.345 & 0.12 & $>0.05$ \\
\hline LDL & 131.32 & 138.27 & 36.112 & 8.285 & 0.75 & $>0.05$ \\
\hline VLDL & 33.80 & 37.46 & 17.188 & 3.943 & 0.96 & $>0.05$ \\
\hline
\end{tabular}


Table 2: Comparative analysis of Overall Effect Group A and Group B

\begin{tabular}{|l|l|l|l|l|l|}
\hline Group A & Group B & Mean Difference & SE $( \pm)$ & T Value & P-Value \\
\hline 20.87 & 10.37 & 10.50 & 3.58 & 3.32 & $<0.05$ \\
\hline
\end{tabular}

Comparative analysis of the overall effect of the treatments in both groups was done statistically with an Unpaired T-Test. The test shows that the treatment is statistically significant in Group A when compared to Group B. Group A overall result is $20.87 \%$ and Group B overall result is $10.37 \%$.

\section{DISCUSSION}

Cardiovascular diseases are the most common cause of death worldwide and Dyslipidemia is considered as one of the reasons. Dyslipidemia is the abnormality in the levels of lipoproteins in the blood. There is no direct correlation in Ayurveda, but it is often correlated with Medo roga. Dyslipidemia is a disorder of Medo Roga where Vata and Kapha and due to which Agni becomes Mandhya. For the Samprapthi Vighatana drugs should possess Vata Kaphahara action with Medohara quality.

\section{Discussion on results in Dyslipidemia}

Group A and Group B treated with Tryushanadhi guggulu and Navaka guggulu respectively showed good results when lipid profile is valued. Tryushanadhi guggulu of Group A was able to treat Dyslipidemia with a statistically significant reduction in Total cholesterol, Triglycerides, LDL cholesterol, VLDL and increasing HDL cholesterol. Navaka guggulu of Group B even though it could reduce the hyper lipids compared to Group A it was less and there was no statistically significant increase in HDL in Group B of Navaka guggulu.

\section{Probable mode of action of Tryushanadhi guggulu} Tryushanadi Guggulu contains Pippali (Piper longum), Maricha (Piper nigrum), Shunti (Zingiber officinale), Chitraka (Plumbago zeylenica), Musta (Cyperus rotundus), Vidanga (Embelia ribes), Vaca Acorus calamus), Shudha Guggulu (Commiphora mukul) and Ghrta (ghee). Vata and Kapha are involved in the pathology of this disease. So, a combination of Snehana and Rukshana is needed to break the pathology. Ghrta which is an ingredient of this preparation is well known when Vata is concerned. It is most effective for balancing Vata and supporting Agni. In the combination of Tryushanadhi guggulu, the concentration of Guggulu is found to be more, which has the Prabhava (special effect) of MedoVatahara and Lekhana(scraping) In this formulation, eight drugs, have dominant Katu Rasa (pungent taste) three Dravyas are having Kashaya (astringent) \& Tikta Rasa (bitter) dominancy. Katu, Tikta \& Kashaya Rasa have potential to pacify the Kapha Dosha. Among these three, Katu rasa has the potential of stimulating the digestive fire \& scraping action, which helps to normalize the Jataragni to form nutritional Anna Rasa as a substrate which further gives qualitative nutrition to the next Dhatus \& help in modification or normalization of Dhatwagni. It also helps to scrape out the Abaddha Mamsa-Medo Dhatus from the body.

Tikta rasa has properties of digestive, carminative, Kleda-Meda Shoshaka, Srotovishodhaka \& potent in Lekhana property, thus helping to break the pathogenesis of Medoroga. Kashaya Rasa also has the property of Sharira-Kleda Shoshana. All these dominant Rasa in this formulation thus helps in the breakage of the pathogenesis of the disease. Besides this, there is dominancy of Laghu (lightness), Ruksha (non-unctuousness) \& Tikshna Gunas (sharpness)in the Tryushnadi Guggulu which also helps in Kaphameda shamana property \& Kleda-medashoshana four Dravyas out of eight in the formulation possesses Tikshna \& Ruksha Guna and all eight Dravyas possesses Laghu Guna.

The formulation of Tryushanadhi guggulu has six Dravyas with dominant Ushna virya (hot potency) which also helps to pacify the Vata-Kapha dosha. With all these properties, Sukshma property of Guggulu helps in Bhedana of Avarana of Samana Vayu. Vatanulomana-Vataharanam properties of some Dravyas help to normalize the Apana vayu. Thus, by controlling the Apanavata, other types of Vata can 
also be normalized in their functions by virtue of all the properties of various Dravyas present in the formulation.

\section{Probable mode of action of Navaka Guggulu} Laghu, Tikshna, Ruksha Gunas, Katu Rasa, Katu Vipaka and Ushna Virya -subsides the aggravated Kapha and relieves Medo Roga. Katu Rasa, Laghu, Ruksha, Tikshna Guna, Katu Vipaka and Ushna Virya- pacify Dushti of Medo dhatu. By the virtue of these Gunas it stimulates Jatharagni which turn in turn stimulates Medo dhatvagni. This corrects the basic pathology of Dyslipidemia. With the help of Katu, Tikta Rasa, Laghu, Tikshna, Ruksha Guna and Ushna Virya, Navaka Guggulu will stop the further Ama production and help to break the basic pathology of Medo Roga. The disease exhibits Sanga type of Sroto Dushti and this combination of Laghu Guna, Tikta Rasa and Ushna Virya relieves Sanga and breaks the Samprapti of Medo Roga.

The digestive (Ama Pachana), appetitive, scrapping, lightness increaser, Vata-kapha palliative properties of these drugs help in the reduction of symptoms. Thus, it eradicates Medoja obstruction by scrapping activity and normalizing Vata.

\section{CONCLUSION}

Dyslipidemia is a disorder of Medoroga where Vata and Kapha and due to which Agni becomes mandhya. For the Samprapthi vighatana, drugs should possess Vata-kapahahara action with Medohara quality. Tryushanahi guggulu and Navaka guggulu mentioned in the Sthoulyadhikara has these properties also. Navaka guggulu is a well-known drug that is used widely. Hence it is taken as a trial drug to compare with Tryushanadhi guggulu which is having almost similar drugs in its combination. It would be a great achievement if we are able to treat such a condition with principles laid by our ancient Acharyas. Keeping this view in mind, the study entitled "A comparative clinical study to evaluate the effectiveness of Tryushanadhi guggulu and Navaka guggulu in Dyslipidemia.

\section{REFERENCES}

1. Tripathi, K. D. Essentials of Medical Pharmacology, India: JP brothers' medical publishers, $6^{\text {th }}$ edition, 2008; pg. 613-614.

2. Yash Pal M, API Textbook of Medicine, Sec 18Disorders of Metabolism, Chap 3- Lipids and Lipoprotein Metabolism Edition 9th, 2012 pg:1235

3. Joseph, D. Pharmacotherapy, A pathophysiological approach, The McGraw Hill Companies, Inc. $8^{\text {th }}$ edition, 2011; pg370.

4. Wouters, K., Shiri-Sverdlov, R., van Gorp, P. J., van Bilsen, M., Hofker, M.H. Understanding hyperlipidemia and atherosclerosis: lessons from genetically modified apoe and ldlr mice. Clin. Chem. Lab. Med., 2005; 43(5):470-9.

5. Charaka Samhita with Charaka Chandrika Commentary by Dr Bramhananda Tripathi, Chikitsa Sthana, Chapter 15/16 Chaukhambha Sanskrit Sansthan, Varanasi, Re Ed 2004, Part 2page no 557.

6. Sushrutha Samhita, Kaviraaj Shastri Ambikadutta, Chaukhambha Sanskrit Sansthan, Varanasi, 2007; 62. 5.

7. Astanga Sangraha Kaviraj Gupta Atrideva, Chaukhaba Krishandas Academy, Varanasi, 2005; pg.183-184.

8. Bhavamishra, Bhavaprakasha commentary by Dr Bulasu Sitaram, 39th chapter Chaukhamba orientalia 1st edition 2010 sloka no.39 page no:439

9. Chakrapani, Chakradatta, P.V. Sharma, 36th Chapter Sloka no:18, Chaukhambha publisher 3rd edition: 2002 Page no:310

\section{Source of Support: Nil \\ Conflict of Interest: None Declared}

How to cite this URL: Merin Jose et al: A Comparative Clinical Study To Evaluate The Effectiveness Of Tryushsanadhi Guggulu And Navaka Guggulu In Dyslipidemia. International Ayurvedic Medical Journal \{online\} 2021 \{cited October 2021\} Available from: http://www.iamj.in/posts/images/upload/2392_2396.pdf 